\title{
Physicochemical Properties Of Sesame Oil And Varietal Susceptibilty To Tribolium Castaneum Herbst (Coleoptera: Tenebrionidae) Infestation
}

\author{
O.O. Oyegoke ${ }^{1}$, S.A. Babarinde ${ }^{2}$, *A. J. Akintola ${ }^{1}$, A. J. Fatoba ${ }^{1} \&$ G. Tona ${ }^{3}$ \\ 1. Department of Pure and Applied Biology, 2. Department of Crop and Environmental \\ Protection, 3. Department of Animal Production and Health, Ladoke Akintola University of \\ Technology, Ogbomoso, Nigeria
}

\begin{abstract}
Five improved sesame varieties (Sesamum indicum) namely E8, 01M, 02M, 03L, and Ex-Sudan were screened in the laboratory for varietal susceptibility to the rust red flour beetle, Tribolium castaneum (Herbst). The physicochemical properties of fixed oil extracted from each variety were also determined. Weight of 100 seeds and mortality of $T$. Castaneum in different sesame varieties were significant $(P<0.05)$. The number of emerged $F_{1}$ larvae from the seeds was significantly different $(P<0.05)$ among the five varieties with the largeseeded variety $(03 L)$ recording the lowest number (1.15). Percentage adult mortality of $T$. castaneum was positively correlated to percentage oil content of the sesame varieties $(r=0.56 ; p<0.01)$; negative correlation was observed between oil $p H$ and larva emergence $(r=0.47 ; p<0.05)$. The importance of some physicochemical parameters of sesame oil as indicators of resistance in sesame seeds to T. castaneum and their potential use to generate resistant lines is implied by this work.
\end{abstract}

keywords: Sesame indicum, Susceptibility, Tribolium castaneum, Varietal resistance

\section{Introduction}

In most developing countries of the world like Nigeria, agriculture forms the main stay of the economy since it is the major occupation of the people; consequently, it remains the driving force for economic growth. However, the profile of agriculture has not changed significantly in most of these countries as it is dominated by small scale farmers; and if the ever increasing human population is taken into consideration, the reason why food scarcity, hunger, and malnutrition have not abated in them can be understood (Aitken, 1975; FAO, 2005b).

One of the problems posed to small scale farmers throughout the world is that of insect pest damage to stored-grains and grain products which can be up to 20-30\% in the tropical regions (Nakatita, 1998). Tribolium castaneum (Coleoptera: Tenebrionidae) is a widespread and destructive secondary pest which attack stored products grains and grain products (Aitken, 1975; Weston and Rattlingourd, 2000). Not only is it capable of breeding throughout the year in warm areas, the insect can live for more than two years, during which the female can produce about 1000 eggs ( Pugazhvendon et al., 2009; Shukla et al., 2010).

Sesame (Sesame indicum L.) seed is one of the world's most important and oldest oilseed crops known to man (Abou- Gharbia et al., 2000). Though sesame seeds were chiefly used in oil and wine production, they are mostly used for oil extraction and edible purposes (El Khier et al., 2008 ; Ghandi, 2009). Sesame seed is not only rich in methionine, it similarly has approximately 50 percent oil (out of which $35 \%$ is monounsaturated fatty acids and $44 \%$ polyunsaturated fatty acids) and 45 percent meal (of which $20 \%$ is protein) (Ghandi, 2009: Hansen, 2011). World production of sesame seeds as estimated by FAO was 3.3 million metric ton as at 2006; in this figure, China and India are the largest producers (USAID, 2009). Africa grows $26 \%$ of the world's sesame, with Sierra leone, Sudan, Nigeria and Uganda being the key producers (Abou-Gharbia et al., 2000). Sesame has become an important component of Nigeria's agricultural export crop as it is cultivated commonly in Northern part of the country (Chemonics, 2002). The Nigerian market potential for sesame seed production has been increasing and the production figures of 98,000,000 to 152,000,000 kg from 2003 to 2007 confirms this (CBN, 2009).

Nigeria as a country has a great market potential for sesame production for both domestic and export markets; the highly priced lighter varieties of sesame such as white, yellow and black are found in the country (Fariku et al., 2007). With many uses of sesame and the existence of several varieties of the plant developed in Nigeria, it has become important to investigate their comparative susceptibility, to stored product insects. Therefore, the objective of this study is to evaluate the susceptibility or resisitance of five improved Nigeria varieties of sesame to infestation of Tribolium castaneum and the physicochemical properties of fixed oil extracted from each hybrid as possible basis for the inherent resisitance. 


\section{Collection of Samples and Storage}

\section{Materials And Methods}

Five varieties of Sesame seeds were obtained from National Cereal Research Institute, Badegi, Bida, Nigeria. The varieties namely, E8, 01M, 02M, 03L, and Ex-Sudan were disinfected by storage at 40C for two weeks before use.

\section{Determination of Seed Weight}

Seed weight was determined by putting a hundred seeds of each sesame variety into $9 \mathrm{~cm}$ diameter Petri dish and weighed using a sensitive weighing balance $\left(\mathrm{Ohaus}{ }^{\circledR}\right)$. Seed weight determination was repeated four times and the mean values determined.

\section{Culturing of Tribolium castaneum}

T. castaneum adults were obtained from a culture maintained in the Storage Entomology Unit of the Department of Crop and Environmental Protection, Ladoke Akintola University of Technology (LAUTECH), Ogbomoso, Nigeria. They were collected and reintroduced into plastic jars containing milled sorghum bought from Sabo market in Ogbomoso. The jars were kept in the laboratory under ambient temperature of $25-35^{\circ} \mathrm{C}$ and relative humidity of $68-80 \%$. With the emergence of larvae after 42 days of infestation, the emerged larvae and adults were separated. The emerged larvae were raised to produce $F_{1}$ generation of beetles. The adulst were used for subsequent infestation to maintain insect culture throughout the period of the experiment.

\section{Antixenosis prescreen}

Antixenosis prescreen was done according to Babarinde et al. (2008) with little modifications. A white cardboard paper was cut into a circular shape of radius $15.5 \mathrm{~cm}$ and divided into 5 equal parts with a smaller internal circle radius $5 \mathrm{~cm}$ at the center. This divided cardboard was placed in a large bowl container of same radius $15.5 \mathrm{~cm}$. The five sesame varieties were randomly allocated to each subdivision. Thirty $T$. castaneum adult were introduced into the inner circle and data on number of insects attracted to each variety was determined. The experiment was replicated four times.

\section{Sesame varietal susceptibility of sesame seeds to $T$. castaneum infestation}

Twenty grams of each sesame variety was separately weighed into $150 \mathrm{ml}$ glass jar with perforated lids covered with a muslin cloth. Ten mixed sex T. castaneum adult (3 day old) were introduced into the jar. After seven days of oviposition, the dead and life insects were removed and counted. Thereafter, the samples were kept for 42 days for the emergence of $F_{1}$ progeny. The experiment was replicated four times.

\section{Oil extraction}

Oil extraction was done with soxhlet apparatus. Fifty grams of each sesame variety was ground with mortar and pestle and extracted with $200 \mathrm{ml} \mathrm{n}$-hexane at $60^{\circ} \mathrm{C}$ for $4 \mathrm{~h}$. Oil was recovered by subjecting the solution into heat for $30 \mathrm{~min}$ so as to allow the solvent to evaporate.

\section{Physico-chemical analysis}

Total Ash and moisture content of each sesame variety and free fatty acid of the sesame oil were determined using AOAC methods (AOAC, 1990): Total Ash, Moisture content, and free fatty acid.

\section{pH determination}

Seeds of each sesame variety were milled using a mortar and pestle. Two grams of each sample was weighed and dispersed in $30 \mathrm{ml}$ of distilled water. The suspension was manually stirred with a glass rod until an equilibrium $\mathrm{pH}$ value and temperature were observed, with the aid of a $\mathrm{pH}$ meter.

\section{Experimental Design and Statistical analysis}

The experiments were set up in completely randomized design (CRD) and data were subject to one way analysis of variance (ANOVA) with the aid of statistical software, SAS (SAS Institute, 2000)

\section{Determination of Seed Weight}

\section{Results}

There was a significant difference $(\mathrm{p}<0.05)$ in the weight of each of the 100 seeds of the five sesame varieties. The highest seed weight $(0.61 \mathrm{~g})$ was recorded in $02 \mathrm{M}$ and $03 \mathrm{~L}$ was significantly higher than the values obtained in Ex-Sudan $(0.56 \mathrm{~g}), 01 \mathrm{M}(0.53 \mathrm{~g})$ and E8 (0.55 g) (Table 1). 


\section{Antixenosis prescreen}

There was no significant difference among sesame varieties with regard to free choice antixenosis. $03 \mathrm{~L}$ had the highest mean number (2.09) of attracted T. castaneum adult, while 02M had the smallest mean number (0.79) of attraction (Table 1$)$

\section{Effect of Sesame varietal resistance on mortality, larval and adult emergence}

Sesame variety significantly $(\mathrm{p}<0.05)$ affected mortality. The highest percentage mortality was observed in 03L (29.35\%), followed by 01M (26.20\%), Ex-sudan (22.50\%) and E8 (18.40\%). The least percentage mortality observed in $02 \mathrm{M}(13.30 \%)$ was significantly lower than mortality observed in 03L. There was significant difference among varieties with regards to adult emergence. The least adult emergence was observed in 03L (0.84) which was significantly lower than the adult emergence observed in Ex-sudan (1.99). Significant difference $(\mathrm{p}<0.05)$ was also recorded with regards to larva emergence. The highest number of emerged larva was observed in 01M (3.71), followed by Ex-sudan (3.56), E8 (2.28) and 02M (1.99). The least number of emerged larvae (1.15) was observed in 03L, which was significantly lower than 3.71 and 3.56 observed in $01 \mathrm{M}$ and Ex-sudan respectively (Table 1).

\section{Physico-chemical properties of the experimented sesame varieties}

There was significant difference among sesame varieties $(\mathrm{p}<0.05)$ with regards to $\mathrm{pH}$. The highest $\mathrm{pH}$ (0.8) was recorded in variety 03L and this was followed by 02M, Ex-Sudan (0.79) and E8 (0.78) in that order The smallest $\mathrm{pH}$ was recorded in $01 \mathrm{M}(0.76)$. FFA contents varied significantly $(\mathrm{p}<0.05)$ among the five sesame varieties. The highest FFA was recorded in 02M variety (34), followed by 01M (30:23), Ex-sudan (27.54) and E8 (19.54). The lowest FFA was recorded in 03L (12.69).

The highest oil content was recorded in variety $03 \mathrm{~L}(0.65)$, which was significantly higher than what was obtained in 01M (0.61), Ex-sudan (0.52), 02M (0.28) and E8 (0.26).

The ash content observed in variety $02 \mathrm{M}$ (14.39), significantly higher than what was obtained E8 (12.54) and $01 \mathrm{M}$ (11.96). There was significant difference among varieties with regards to moisture content. The moisture content observed in Ex-sudan (15.36\%), E8 (15.25\%), 02M (15.05\%) and 01M (14.49\%) was significantly higher than $14.03 \%$ obtained in $03 \mathrm{~L}$ (Table 2 ).

Correlation of physiochemical properties of sesame and reproductive parameters of Tribolium castaneum

There was a positive correlation between mortality and oil content $(\mathrm{r}=0.558 ; \mathrm{P}<0.01)$. Positive correlation was observed between adult emergence and larva emergence $(r=0.624 ; \mathrm{P}<0.05)$. The ash content and $\mathrm{pH}$ of oil extracted from sesame were negatively correlated to mean seed weight $(\mathrm{r}=-0.471 ; \mathrm{p}<0.05 ; \mathrm{r}=$ $0.716, \mathrm{p}<0.01)($ Table 3).

\section{Discussion}

The sesame variety with the lowest moisture content and highest oil yield (O3L) recorded the least larva and adult emergences and highest percentage mortality. These observations are similar to the findings of Rahman et al., (2003) who reported that sesame with high oil content result in lower infestation, less emergence of adult, less seed damage, and a higher inhibition rate upon attack by $T$. castaneum. In a similar study in another Coleopteran, Khaire et al., (1992) reported that sesame oil inhibited the emergence of adult Callosobrunchus chinensis. In addition, Mohuiddin et al., (1993) reported the toxicity of oil of different plants including Sesamum indicum on T. castaneum.

T. castaneum as an insect pest is known to complete its development from eggs to imago stage in about 28 days under optimal temperature condition and moisture content of $31^{\circ} \mathrm{C}$ and $15 \%$ respectively. Consequently, lower moisture contents are inimical to the proliferation and infestation by these beetles (PHPG, 1986). The important role of lower moisture content could be one of the reasons for the least values posted for adult and larval emergences of the beetles in O3L variety. Furthermore, the variety posted the highest adult mortality.

The positive correlation between percentage mortality of $T$. castaneum with oil content of sesame implies that large seeded variety with high oil content inhibits infestation by T. castaneum beetles. Therefore, breeding for high oil yield can be precursory to inherent resistance against $T$. castaneum infestation.

Of the five studied varieties, $03 \mathrm{~L}$ showed greater potentials for inherent resistance against T. castaneum than others. This variety is, therefore, recommended for farmers in areas that are prone to T. castaneum infestation. Since O3L is a large seeded variety with high oil yield, it will not be difficult for farmers to adopt, provided it does not have any other negative agronomic qualities on the field. The most attractive feature of using varietal resistance is that it does not require extra technical skill or financial costs (Babarinde et al., 2008). Breeders can also utilize this variety for crosses to produce better quality sesame hybrids. 


\section{References}

[1]. Abou-Gharbia, H.A., Shehata, A.A.Y, and Shahidi, F. (2000). Effect of processing on oxidative stability and lipid classes of sesame oil. Food Research International, 33, 331-340.

[2]. AOAC. (1995). Official Methods of Analysis. 16th Edn., Association of Official Analytical Chemists, Washington, DC, USA.

[3]. Aitken, A.D. (1975). Insect traveller. Volume 1. Coleoptera Technical Bulletin 31, London (UK): H.M.S.O.

[4]. Babarinde, S.A., Adebayo, M.A, and Oduyemi,K. (2008). Integrating varietal resistance with Xylopia aethiopica (Dunal) A. Richard seed extract for the management of Sitophilus zeamais Motschulsky in stored maize. Afr. Jour. Biotech, 7(8): 1187-1191.

[5]. Post Harvest Pocket Guide (1986). Stored-grain insects. Integrated Pest Management Purdue University Cooperative Extension Services. ID 215. Agric Handbook Nos 500. p.101

[6]. Chemonics International Inc. (2002). Overview of the Nigerian Sesame Industry. The United States Agency for International Development (USAID)/Nigeria RAISE IQC Contract No. PCE-1- 00-99-000-00.

[7]. CBN (2009). Annual Report and Statements of Accounts for the Year ended 31st December, 2008. Central Bank of Nigeria, 2009; 142-145.

[8]. Cotton and Wallac

[9]. El khier, M.K.S, Ishaq, K.E.A and Yagoud, A.E.A (2008).Chemical Composition and Oil Characteristics of sesame seed Cultivars grown in Sudan. Research Journal of Agriculture and Biological Sciences, 4(6): 761- 766.

[10]. FAO (2005). The State of Food Insecurity in the World.

[11]. Fariku, S, Ndonya, A.E , and Bitrus, P.Y.(2007). Biofuel characteristics of beniseed (Sesame indicum) Oil. African Journal of Biotechnology Vol. 6(21), pp. 2442-2443.

[12]. Ghandi, A.P (2009). Simplified process for the production of sesame seed (Sesame indicum L). butter and its nutritional profile. Asian Journal of Food and Agro-Industry. 2(01): 24-27.

[13]. Hansen, R. (2011).Sesame Profile. 19/08/11. Available at http;//www.agmrc.org/commodities products/grains_oilseeds/sesame_profile.cfm

[14]. Khaire, V.M., BKachare, B.V., and Mote, U.N. (1992). Efficacy of different vegetable oils as grain protecteants against pulse beetle (Callosobruchus chinesis) L in inceasing storability of pigeon peas. J.Std. Prod. Res., 28 (3): 153-156.

[15]. Mohiuddin, S., Quireshi, R.A., Ahmed, Z., Quireshi, S.A., Jamil, K., Jyothi,K.N and Prasuna, A.L. (1993). Laboratory evaluation of some vegetable oils as protectants of stored products. Pak. J. Sci. Indust. Res., 36(9): 377-379.

[16]. Nakakita, H. (1998). "Stored rice and stored product insects". In Rice inspection technology manual, 49-65, Tokyo (Japan): A.C.E. Corporation.

[17]. Pugazhvendon, S.R., Elumalai, K, Ronald-Ross, P. and Soundararajan, M.(2009). Repellent activity of chosen plant species against Tribolium castaneum. W.J. Zool, 4(3):188-190.

[18]. Rahman, M.A., Taleb, M.A. and Biswas, M.M. (2003). Evaluation of botanical products as grain protectant against grain weevil, Sitophilus granaries on wheat. Asian J. Plant Sci., 2960: 501-504

[19]. SAS Institute (2000): Statistical analytical systems, SAS/STAT User's guide version 8(2). SAS Institute, Cary, NC, USA

[20]. Shukla, G.S., Upadhyay, V.B., Mathur, R. and Prasad, S.G. (2010). Economic zoology, biostatistics and animal behavior, Meerut (India): Rastogi Publication.

[21]. Weston, P.A. and Rattlingourd, P.A. (2000).Progeny Production by Tribolium castaneum (Coleoptera: Tenebrionidae) and Oryzaephilus surinamensis (Coleoptera: Silvanidae) on maize Previously infested by Sitotroga cerealla (Lepidoptera: Gelechiidae). J.Econ. Entomol. 93:533-535.

Table 1. Sesame seed weight and effect of varietal difference on adult mortality, antixenosis, larval and adult

\begin{tabular}{|c|c|c|c|c|c|c|}
\hline Variety & Weight of 100 & Mortality & $\begin{array}{r}\text { emergen } \\
\text { Antixenosis } \\
\end{array}$ & Larva & Adult & \\
\hline & Seeds & $(\%)$ & & emergence & emergence & \\
\hline $01 \mathrm{M}$ & $0.53^{\mathrm{a}}$ & $26.20^{\mathrm{ab}}$ & $1.51^{\mathrm{a}}$ & $3.71^{\mathrm{a}}$ & & $0.97^{\mathrm{b}}$ \\
\hline $02 \mathrm{M}$ & $0.61^{\mathrm{c}}$ & $13.30^{\mathrm{b}}$ & $0.79^{\mathrm{a}}$ & $1.99^{\mathrm{ab}}$ & $0.93^{\mathrm{b}}$ & \\
\hline 03L & $0.61^{\mathrm{c}}$ & $29.35^{\mathrm{a}}$ & $2.09^{\mathrm{a}}$ & $1.15^{\mathrm{b}}$ & $0.84^{\mathrm{b}}$ & \\
\hline E8 & $0.55^{\mathrm{ab}}$ & $18.40^{\mathrm{ab}}$ & $1.39^{\mathrm{a}}$ & $2.28^{\mathrm{ab}}$ & & $1.13^{\mathrm{ab}}$ \\
\hline Ex-Sudan & $0.56^{\mathrm{ab}}$ & $22.50^{\mathrm{ab}}$ & $1.32^{\mathrm{a}}$ & $3.56^{\mathrm{a}}$ & $1.99^{\mathrm{a}}$ & \\
\hline LSD & 0.02 & 13.68 & 1.39 & 1.84 & & 0.94 \\
\hline
\end{tabular}

Mean followed by the same letter within the column are not significantly different $(\mathrm{p}<0.05)$ using LSD

Table 2: $\quad$ Selected Chemical Properties of the Five Sesame varieties

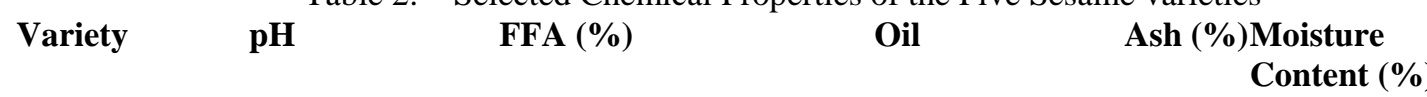

$\begin{array}{lllllr}01 \mathrm{M} & 0.76^{\mathrm{d}} & 30.23^{\mathrm{b}} & 0.61^{\mathrm{b}} & 11.96^{\mathrm{b}} & 14.97^{\mathrm{a}} \\ \text { 02M } & 0.79^{\mathrm{b}} & 34.00^{\mathrm{a}} & 0.28^{\mathrm{d}} & 14.39^{\mathrm{a}} & 15.05^{\mathrm{a}} \\ \text { 03L } & 0.80^{\mathrm{a}} & 12.69^{\mathrm{e}} & 0.65^{\mathrm{a}} & 13.42^{\mathrm{ab}} & 14.03^{\mathrm{b}} \\ \text { E8 } & 0.78^{\mathrm{c}} & 19.54^{\mathrm{d}} & 0.26^{\mathrm{c}} & 12.54^{\mathrm{b}} & 15.25^{\mathrm{a}} \\ \text { Ex-sudan } & 0.79^{\mathrm{b}} & 27.54^{\mathrm{c}} & 0.52^{\mathrm{c}} & 13.68^{\mathrm{ab}} & 15.36^{\mathrm{a}} \\ \text { LSD } & 0.01 & 0.3 & 0.004 & 1.74 & 0.81\end{array}$


Physicochemical Properties Of Sesame Oil And Varietal Susceptibilty To Tribolium Castaneum

Means followed by different superscripts within the column are not significantly different ( $<<0.05)$ using LSD.

Table 3: Correlation (r) of physicochemical properties of sesame and reproductive parameters of

T. castaneum studied sesame varieties

\begin{tabular}{|c|c|c|c|c|c|c|c|c|c|c|}
\hline & $\mathrm{pH}$ & Ash & Moisture & Mortality & Antixenosis & $\begin{array}{l}\text { Adult } \\
\text { emerge }\end{array}$ & Larva emerge & FFA & Weight & Oil content \\
\hline $\mathrm{pH}$ & 1 & 0.404 & -0.225 & -0.026 & -0.107 & 0.009 & $-0.470^{*}$ & -0.410 & $-0.716^{* *}$ & 0.050 \\
\hline Ash & & 1 & -0.072 & -0.011 & -0.293 & -0.129 & -0.429 & 0.125 & $-0.471 *$ & -0.182 \\
\hline Moisture & & & 1 & -0.242 & -0.414 & 0.157 & 0.322 & 0.411 & 0.280 & -0.372 \\
\hline Mortality & & & & 1 & 0.117 & -0.231 & -0.268 & -0.350 & 0.109 & $0.558 * *$ \\
\hline Antixenosis & & & & & 1 & -0.021 & 0.062 & -0.399 & 0.018 & 0.357 \\
\hline Adult emerge & & & & & & 1 & $0.624 * *$ & 0.128 & 0.164 & 0.016 \\
\hline Larva Emerge & & & & & & & 1 & 0.418 & 0.416 & 0.114 \\
\hline FFA & & & & & & & & 1 & 0.156 & -0.297 \\
\hline Weight & & & & & & & & & 1 & 0.078 \\
\hline Oil content & & & & & & & & & & 1 \\
\hline
\end{tabular}

*Significant correlation at 5\% probability level

** Significant correlation at $1 \%$ probability level 